\title{
Protein Kinase C Delta Type
}

National Cancer Institute

\section{Source}

National Cancer Institute. Protein Kinase C Delta Type. NCI Thesaurus. Code C150120.

Protein kinase $C$ delta type ( $676 \mathrm{aa}, \sim 78 \mathrm{kDa}$ ) is encoded by the human PRKCD gene. This protein plays a role in the regulation of apoptosis. 